Marchelli, P. and L. A. Gallo (2000): Variación aloenzimática, de $\mathrm{ADN}$ de cloroplasto y de $\mathrm{ADN}$ nuclear en poblaciones y progenies de raulí en Argentina. pp 157-180. In: Domesticación y mejora genética de raulí y roble, edited by IPINZA, R., GutiÉRrez, B. and EMHART, V. Universidad Austral de Chile, Instituto Forestal, Valdivia, Chile.

Marchelli, P. and L. A. Gallo (2001): Genetic diversity and differentiation in a southern beech subjected to introgressive hybridisation. Heredity 87, 284-293.

MARChELli, P. and L. A. GALlo (2006): Multiple ice-age refugia in a southern beech from southern South America as revealed by chloroplast DNA markers. Conservation Genetics 7, 591-603.

Mattioni, C., M. Casasoli, M. Gonzalez, R. Ipinza and F. VILLANI (2002): Comparison of ISSR and RAPD markers to characterize three Chilean Nothofagus species. Theoretical and Applied Genetics 104, 1064-1070.

Premoli, A. C. (1997): Genetic variation in a geographically restricted and two widespread species of South American Nothofagus. Journal of Biogeography 24, 883-892.
RAYMOND, M. and F. Rousset (1995): GENEPOP: Population Genetics Software for exact tests and ecumenicism. The Journal of Heredity 86, 248-249.

Rozen, S. and H. J. Skaletsky (2000): Primer3 on the WWW for general users and for biologist programmers. pp 365-386. In: Bioinformatics Methods and Protocols: Methods in Molecular Biology, edited by KRAwETZ, S., Misener, S. Humana Press, Totowa, NJ.

Stecconi, M., P. Marchelli, P. Picca, J. Puntieri and L. A. Gallo (2004): Natural hybridization between a deciduous (Nothofagus antarctica) and an evergreen (N. dombeyi) forest tree species as evidenced by morphological and isoenzymatic traits. Annals of Botany 94, 775-786.

Streiff, R., T. Labbe, R. Bacilieri, H. Steinkellner, J. GLÖSSL and A. KREMER (1998): Within population genetic structure in Quercus robur L. and Quercus petraea (Matt.) Liebl. assessed with isozymes and microsatellites. Molecular Ecology 7, 317-328.

\title{
Genetic Variation in the Qinghai-Tibetan Plateau Endemic and Endangered Conifer Cupressus gigantea, Detected Using RAPD and ISSR Markers
}

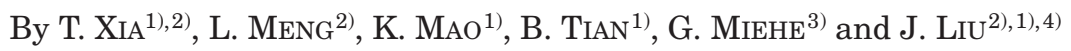 \\ MOE Key Laboratory of Arid and Grassland Ecology, \\ School of Life College, Lanzhou University, Lanzhou, 730000, China
}

(Received 21 $1^{\text {th }}$ September 2007)

\begin{abstract}
Assessing the level and distribution of genetic diversity of rare tree species is essential for their management and the development of effective conservation strategies. Cupressus gigantea is a long-lived endemic cypress of the west Qinghai-Tibetan Plateau and the tallest tree in its genus. The current populations of this species are fragmented and highly disturbed. We used RAPD (Random Amplified Polymorphic DNA) and ISSR (Inter-Simple Sequence Repeat amplification) markers to assess the genetic variation and population structure of this

1) MOE Key Laboratory of Arid and Grassland Ecology, School of Life College, Lanzhou University, Lanzhou, 730000, China.

2) Laboratory of Adaptation and Evolution of Plateau Biota, Northwest Plateau Institute of Biology, Chinese Academy of Sciences, Xining, 810001, Qinghai, China.

$\left.{ }^{3}\right)$ Faculty of Geography, University of Marburg, Deutschhausstr. 1035032 Marburg, Germany.

$\left.{ }^{4}\right)$ Corresponding author: Dr. JIANQUAN LIU (MOE Key Laboratory of Arid and Grassland Ecology, Lanzhou University, Lanzhou, 730000, China. Tel. +86-971-6153387, Fax. +86-971-6143282. E-mail: liujq@nwipb.ac.cn
\end{abstract}

endangered cypress. The 15 RAPD primers used in this study amplified 108 reproducible bands, 49 (45.4\%) of which were polymorphic, while the 12 ISSR primers amplified 94 bands, $65(69.2 \%)$ of which were polymorphic. Analysis of Molecular Variance (AMOVA) indicated that $49.7 \%$ and $38.3 \%$ of the variation was attributable to differences between populations for the RAPD and ISSR markers, respectively; relatively high compared to values reported for other conifer species. These estimates were also similar to Gst values obtained from Nei's gene diversity analyses $(\mathrm{RAPD}=0.41$ and ISSR = 0.36 ), and suggest that there is a high degree of population differentiation in this narrowly-distributed conifer. The genetic structure of this species has probably been shaped by its long life cycle and climatic changes during the Quaternary. The high degree of population differentiation in this species highlights the need for additional conservation measures, including measures to protect of all of the remaining populations. The substantial similarities between the results of the RAPD and ISSR analyses of samples from the same individuals indicate that they can be interpreted with high levels of confidence. 
Key words: Cupressus gigantea, genetic diversity, ISSR, RAPD, Qinghai-Tibetan Plateau.

\section{Introduction}

Genetic diversity provides the potential for tree species to adapt to long-term environmental change (HEDRICK, 2004). An overall loss of genetic variability usually has deleterious effects on species fitness and may threaten the ability of populations to survive and persist via natural regeneration (REED, 2003; KREMER and REviRON, 2004). Assessing the level and distribution of genetic diversity within tree species is crucial for their management and the development of effective conservation strategies, especially for rare species (HEDRICK, 2004). A large number of studies focusing on the pattern and distribution of genetic variation within coniferous tree species have suggested that they have relatively high levels of genetic variation, with little differentiation among populations, compared with other plant taxa (HAMrick et al., 1992; PETIT et al., 2004, 2005). This is mainly because most conifers have widespread distributions, outcrossing breeding systems, and relatively high potential for long-distance gene flow. However, exceptions have been recorded for a limited number of endangered coniferous species. For instance, low genetic diversity has been detected in Abies bracteata (D. Don) D. Don ex Poit (LeDig, 1987) and Calocedrus macrolepis Kurz (WANG et al., 2004), while low intraspecific variation and high population differentiation has been found in Juniperus thurifera Linn. (JIMÉNEZ et al., 2003). These exceptional patterns are thought to be consequences of genetic bottlenecks when populations were reduced in size during the Quaternary glaciations and founder effects during postglacial re-colonizations (e.g. HAMRICK et al., 1992; JIMÉNEZ et al., 2003; WANG et al., 2004; Allnutt et al., 2003; Cottrell et al., 2005; Petit et al., 2005; ZHANG et al., 2005).

Cupressus gigantea CHENG and Fu occurs sparsely along 200 kilometres of the Yarlung (Zangbo) river at altitudes ranging between $3000 \mathrm{~m}$ and $3400 \mathrm{~m}$, on the Qinghai-Tibetan Plateau (QTP), southeast Tibet (FU et al., 1999). This species is listed as threatened, with several relict populations forming pure stands (FU, 1995). C. gigantea individuals can reach diameters up to $6 \mathrm{~m}$, heights exceeding $30 \mathrm{~m}$ and can live for more than 2000 years in the Bajie population near Linzhi county (FU et al., 1999). These are the tallest known members of the Cupressaceae in the world. According to the IUCN categories of threat, this species is classified as rangerestricted and vulnerable (Fu et al., 1999). However, only one population in Linzhi has been protected by the designation of a local "natural protection" region, and most materials used in artificial regeneration programs conducted by the local governments have originated from this population (NAEP and IBCAS, 1987; FU et al., 1999). Furthermore, despite the threatened status of this species, little is known about the genetic variation within and between its populations.

In the study presented here we used Randomly Amplified Polymorphic DNA (RAPD) and Inter-Simple Sequence Repeat (ISSR) markers to estimate the amount and partitioning of genetic diversity between populations in this species. RAPDs are being increasingly used to assess genetic variation in tree species (ALL-

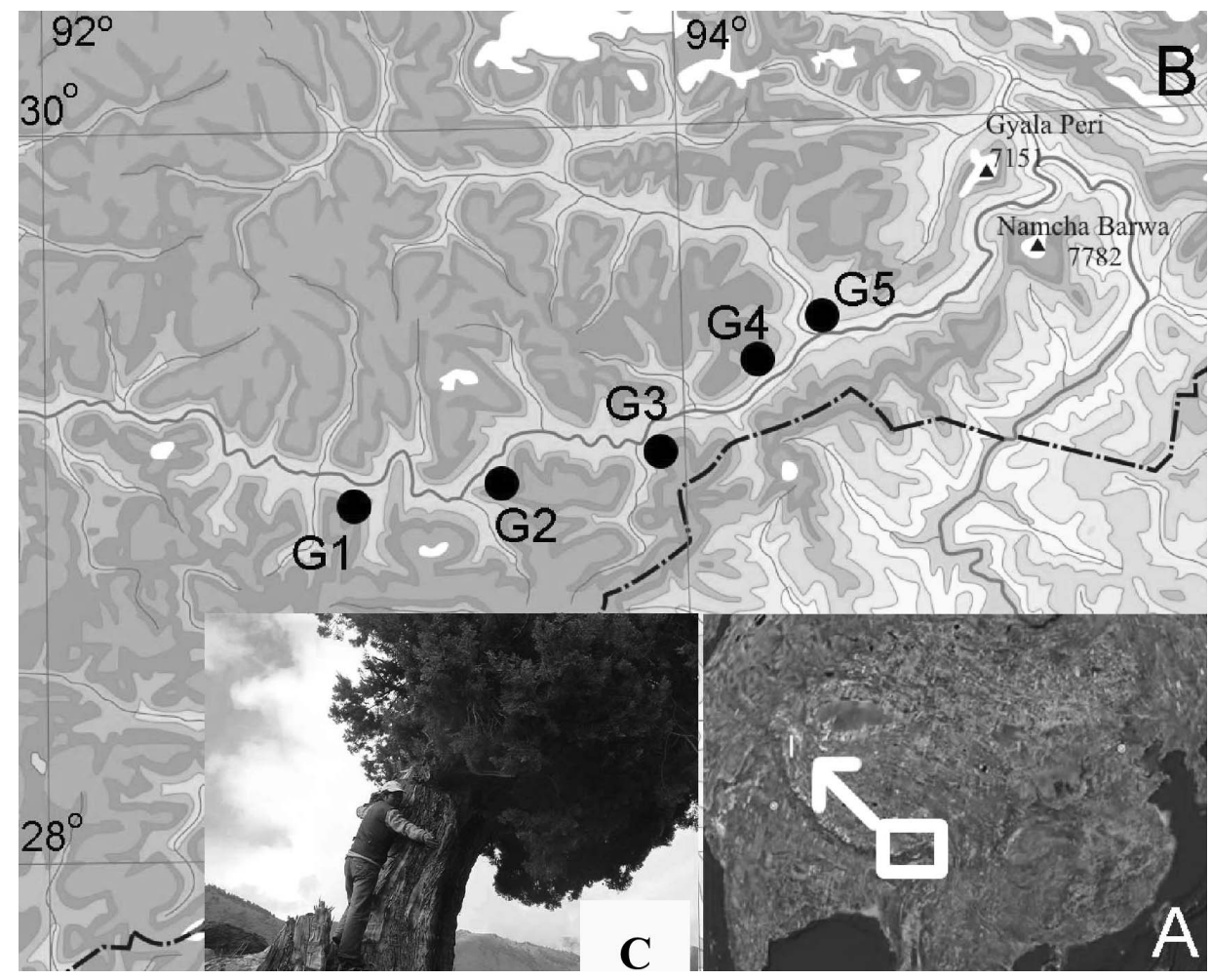

Figure 1. - Maps showing sampling locations (A) and (B), and photograph showing gross morphology of Cupressus gigantea (C). 
NUTT et al., 1999, 2003; BEKESSY et al., 2002; GILLIES et al., 1997, 1999) because DNA sequence information is not required prior to investigating a previously unstudied species using them, which facilitates their application to a wide range of taxa (NEWTON et al., 1999; WANG and SzMIDT, 2001). However, RAPD markers have several limitations including dominance, uncertain locus homology, and their sensitivity to PCR reaction conditions. As dominant markers, ISSRs target simple sequence repeats (microsatellites) that are abundant throughout the eukaryotic genome, evolve rapidly, and thus provide a much larger number of polymorphic fragments per primer than RAPDs. Since no prior knowledge of the DNA sequence is required to design primers (WoLfE et al., 1998), ISSR markers have recently been used to assess the levels of genetic diversity of some coniferous trees (e.g. WANG et al., 2004). Similar levels of genetic diversity and its partitioning among populations of a herb species have been found using both RAPD and ISSR markers (QIAN et al., 2001; NYBOM, 2004). However, results obtained by RAPD and ISSR analyses of populations of single coniferous tree species have not been directly compared in any published studies to date. The main objectives of this study were to address the following questions. How is the genetic diversity partitioned within and among populations of $C$. gigantea? Do the results obtained by analyses of the genetic structure of a species using RAPD and ISSR markers significantly differ, and if so, which marker is the more informative?

\section{Methods}

\section{Sample collection}

The distribution range of $C$. gigantea was investigated in 2001 and 2002. Three large populations containing more than 1000 individuals were found and at least 20 individuals from each of these populations were sampled (Table 1). However, two populations from Lang County contained less than 100 individuals, so we collected only 11 and six trees respectively from these two populations in order to retain a minimum sampling distance of 100 $\mathrm{m}$ between the sampled trees. These populations covered the total distribution range of this species along the Yarlung (Zangbo) river (Figure 1). All of the voucher specimens were deposited in the herbarium of the Northwest Plateau Institute of Biology, the Chinese Academy of Sciences, Xining, Qinghai, China.

\section{DNA extraction and PCR reactions}

All DNA was extracted according to the protocol described by Doyle and Doyle (1987). Initially 60 random decamer primers (Sangon Technologies, Shanghai, China) and 100 ISSR primers (UBC, Vancouver, Canada) were screened, but only 15 RAPD and 12 ISSR primers (Table 2) were used in the final analyses. These primers were chosen because they generated clear, reproducible banding patterns. We used the same PCR reaction kits, PCR machine and electrophoresis equipment for all the amplifications to maximize the unifor-

Table 1. - The locations of the sampled Cupressus gigantea populations and the number of plants sampled at each site $(\mathrm{N})$.

\begin{tabular}{cccccc}
\hline Population & $\mathrm{N}$ & Region & Altitude $(\mathrm{m})$ & Latitude (N) & Longitude (E) \\
\hline G1 & 23 & Langri County & 3200 & $29^{\circ} 02^{\prime} 29^{\prime \prime}$ & $93^{\circ} 03^{\prime} 23^{\prime \prime}$ \\
G2 & 11 & Lang County & 3060 & $28^{\circ} 59^{\prime} 57^{\prime \prime}$ & $93^{\circ} 14^{\prime} 06^{\prime \prime}$ \\
G3 & 6 & Lang County & 3050 & $29^{\circ} 01^{\prime} 19^{\prime \prime}$ & $93^{\circ} 53^{\prime} 02^{\prime \prime}$ \\
G4 & 23 & Milin County & 2950 & $29^{\circ} 20^{\prime} 24^{\prime \prime}$ & $94^{\circ} 22^{\prime} 38^{\prime \prime}$ \\
G5 & 23 & Linzhi County & 3040 & $29^{\circ} 40^{\prime}$ & $94^{\circ} 20^{\prime}$ \\
\hline
\end{tabular}

Table 2. - Primers used for RAPD and ISSR marker amplification.

\begin{tabular}{|c|c|c|c|c|c|c|c|}
\hline \multirow[b]{2}{*}{ Primers } & \multicolumn{3}{|c|}{ RAPD } & \multicolumn{4}{|c|}{$\mathrm{ISSR}^{\mathrm{a}}$} \\
\hline & $\begin{array}{r}\text { Sequence } \\
\left(5^{\prime}-3^{\prime}\right)\end{array}$ & Primer & Sequence $\left(5^{\prime}-3^{\prime}\right)$ & Primers & $\begin{array}{c}\text { Sequence } \\
\left(5^{\prime}-3^{\prime}\right)\end{array}$ & Primers & $\begin{array}{c}\text { Sequence } \\
\left(5,-3{ }^{\prime}\right)\end{array}$ \\
\hline AA-3 & TCTCGCCTAC & $\mathrm{AG}-10$ & ACTGCCCGAC & UBC-807 & $(\mathrm{AG})_{8} \mathrm{~T}$ & UBC-824 & $(\mathrm{TC})_{8} \mathrm{G}$ \\
\hline AA-11 & CAATCGGGTC & AG-14 & CTCTCGGCGA & UBC-808 & $(\mathrm{AG})_{8} \mathrm{C}$ & UBC-841 & $(\mathrm{GA})_{8} \mathrm{YC}$ \\
\hline AA-16 & AACGGCCTAC & AG-20 & TGCGCTCCTC & UBC-811 & $(\mathrm{GA})_{8} \mathrm{C}$ & UBC-847 & $(\mathrm{CA})_{8} \mathrm{RC}$ \\
\hline AA-17 & AGCGGAAGTG & G-01 & CAACGGAGGA & UBC-812 & $(\mathrm{GA})_{8} \mathrm{~A}$ & UBC- 848 & $(\mathrm{CA})_{8} \mathrm{RG}$ \\
\hline AG-4 & GGAGCGTACT & G-07 & GAACCTGCGG & UBC-815 & $(\mathrm{CT})_{8} \mathrm{G}$ & UBC-857 & $(\mathrm{AC})_{8} \mathrm{YG}$ \\
\hline AG-7 & CACAGACCTG & $\mathrm{H}-01$ & GGTCGGAGAA & UBC-818 & $(\mathrm{CA})_{8} \mathrm{G}$ & UBC- 858 & $(\mathrm{TG})_{8} \mathrm{RT}$ \\
\hline AG-8 & AAGAGCCCTC & $\mathrm{H}-10$ & CCTACGTCAG & & & & \\
\hline AG-9 & CCGAGGGGTT & & & & & & \\
\hline
\end{tabular}

a) $\mathrm{Y}: \mathrm{C} / \mathrm{T} ; \mathrm{R}: \mathrm{A} / \mathrm{G}$ 
mity of the reaction conditions and minimize systematic errors.

All reactions were performed in a Tpersonal 20 thermocycler (Whatman Inc., Germany). The thermal program used for RAPD primer amplifications was 5 min at $94^{\circ} \mathrm{C}$ followed by 36 cycles of $50 \mathrm{sec}$ at $94^{\circ} \mathrm{C}, 80 \mathrm{sec}$ at $37^{\circ} \mathrm{C}, 120 \mathrm{sec}$ at $72^{\circ} \mathrm{C}$, and a final extension step of 7 min at $72^{\circ} \mathrm{C}$. Reactions were performed in final volumes of $20 \mu \mathrm{l}$, containing $50 \mathrm{mM}$ Tris- $\mathrm{HCl}(\mathrm{pH} 8.3), 500 \mu \mathrm{g} / \mathrm{ml}$ BSA, $10 \%$ Ficoll, $1 \mathrm{mM}$ tartrazine, $1.5 \mathrm{mM} \mathrm{MgCl}_{2}$, $200 \mu \mathrm{M}$ dNTPs, $1.0 \mu \mathrm{M}$ of each primer, approx. $100 \mathrm{ng}$ of DNA template, $1 \mathrm{U}$ Taq polymerase and $4 \%$ DMSO. The thermal program for ISSR amplifications was an initial 5 min at $94^{\circ} \mathrm{C}$, followed by 38 cycles of $30 \mathrm{sec}$ at $94^{\circ} \mathrm{C}$, $45 \mathrm{sec}$ at $50^{\circ} \mathrm{C}, 1 \mathrm{~min} 30 \mathrm{sec}$ at $72^{\circ} \mathrm{C}$, and a final extension step of $7 \mathrm{~min}$ at $72^{\circ} \mathrm{C}$. Reactions were carried out in volumes of $20 \mu \mathrm{l}$, containing $50 \mathrm{mM}$ Tris- $\mathrm{HCl}(\mathrm{pH} 8.3)$, $500 \mu \mathrm{g} \mathrm{ml}{ }^{-1}$ BSA, $10 \%$ Ficoll, $1 \mathrm{mM}$ tartrazine, $2 \mathrm{mM}$ $\mathrm{MgCl}_{2}, 200 \mu \mathrm{M}$ dNTP, .0.9 $\mu \mathrm{M}$ of each primer, 20-100 ng of DNA template, $1 \mathrm{U}$ Taq polymerase and $4 \%$ DMSO. All amplification products were separated by electrophoresis in a $2.0 \%$ agarose gel in $1 \times$ TBE buffer, stained with ethidium bromide and viewed on a UV transilluminator (Bio-Rad). The molecular weights of the bands were estimated using a $100 \mathrm{bp}$ DNA ladder (Casarray, Shanghai, China).

\section{Data analysis}

Only clear, polymorphic fragments that could be scored across all population samples were used in our analysis. These fragments were scored independently as present (1) or absent (0) in each population, and a binary data matrix was constructed. Both RAPD and ISSR fragments were analyzed as alleles, under the three following assumptions: RAPD products segregate as dominant alleles in a Mendelian fashion; the populations in this study were in Hardy-Weinberg equilibrium; the RAPD fragments represent the nuclear genome and fragments of the same apparent size in different trees are homologous. We used POPGENE version 1.31 (YEH et al., 1999) to calculate a set of intra- and inter-population genetic parameters, including genetic diversity within populations $\left(H_{S}\right)$, genetic diversity between populations $\left(D_{S T}\right)$ and the relative magnitude of genetic differentiation among populations $\left(G_{S T}=H_{T}-H_{s} / H_{T}\right)$. Nei's gene diversity $\left(H_{e}\right)$ was also calculated (NEI, 1973).
Shannon's indices (LEWONTIN, 1972) were also calculated and used to characterize the gene diversity and distribution of the variation, based on the formula $H_{0}=$ $-\sum$ pilog $p_{i}$, in which $p_{i}$ is the frequency of a given RAPD fragment. $H_{0}$ was calculated at two levels: the average diversity within populations (Hpop) and the total diversity $(H s p)$. The proportion of diversity among populations was estimated as (Hsp-Hpop)/Hsp.

Analysis of Molecular Variance (AMOVA, ExCOFFIER et al., 1992) was performed on a matrix of squared standard Euclidean distances. Input data files for the AMOVA version 1.55 program (ExCOFFIER et al., 1992) were generated using AMOVA-PREP (MILLER, 1998). The variance components were tested statistically by nonparametric randomization tests using 1000 permutations. To examine the genetic relationship among populations, a dendrogram was also constructed using the unweighted paired group method of cluster analysis using arithmetic averages (UPGMA) with the computer programme NTSYSpc version 2.02c (ROHLF, 1997).

\section{Results}

\section{Genetic diversity}

Of the 50 RAPD primers screened, 15 produced clear RAPD patterns. The screening of the entire sample set was repeated with two of the primers to assess the repeatability of the RAPD profiles, and we obtained identical RAPD patterns. One hundred and eight clear and repeatable RAPD bands were scored. The average number of bands was 8.3 per primer. Of the 108 RAPD bands scored, 49 (45.4\%) were polymorphic, based on the $95 \%$ criterion. The total gene diversity at the species level $(\mathrm{Ht})$ and Nei's gene diversity $(\mathrm{He})$ were estimated to be 0.124 and 0.121 . The Shannon indices (Hpop) of the $C$. gigantea populations ranged from 0.08 to 0.13 , with an average of 0.10 at the population level (Hpop) and 0.18 at the species level $(H s p)$.

Screening of the entire set of samples using the 12 selected ISSR primers generated a total of 94 bands ranging in length from 230 to $1500 \mathrm{bp}$, corresponding to an average of 10.6 bands per primer, of which 65 were polymorphic $(69.2 \%)$. The total gene diversity at the species level $(H t)$ and Nei's gene diversity $(\mathrm{He})$ were estimated to be 0.19 and 0.20 . The Shannon indices (Hpop) for the populations ranged from 0.15 to 0.21 , with an

Table 3. - Genetic variation in five populations of Cupressus gigantea.

\begin{tabular}{|c|c|c|c|c|c|c|c|c|c|c|}
\hline \multirow{2}{*}{ Population } & \multicolumn{5}{|c|}{ RAPD } & \multicolumn{5}{|c|}{ ISSR } \\
\hline & $\mathrm{N}_{\mathrm{B}}$ & $\mathrm{N}_{\mathrm{PB}}$ & PPB \% & $H_{e}$ & Нрор & $\mathrm{N}_{\mathrm{B}}$ & $\mathrm{N}_{\mathrm{PB}}$ & РPB \% & $H_{e}$ & Hрop \\
\hline G1 & 100 & 33 & 33.00 & 0.0644 & 0.0989 & 82 & 40 & 48.78 & 0.1280 & 0.1882 \\
\hline G2 & 98 & 37 & 37.76 & 0.0845 & 0.1277 & 87 & 46 & 52.87 & 0.1335 & 0.1993 \\
\hline G3 & 91 & 27 & 29.67 & 0.0684 & 0.1002 & 83 & 44 & 53.01 & 0.1422 & 0.2068 \\
\hline G4 & 97 & 30 & 30.92 & 0.0544 & 0.0845 & 80 & 37 & 46.25 & 0.1019 & 0.1532 \\
\hline G5 & 96 & 28 & 29.17 & 0.0570 & 0.0869 & 88 & 48 & 54.55 & 0.1187 & 0.1833 \\
\hline Total & 108 & 49 & 45.37 & 0.1160 & 0.1762 & 94 & 65 & 69.15 & 0.1892 & 0.2847 \\
\hline
\end{tabular}

$\mathrm{N}_{\mathrm{B}}=$ total number of bands; $\mathrm{N}_{\mathrm{PB}}=$ number of polymorphic bands; $\mathrm{P}_{\mathrm{PB}}=$ percentage of polymorphic bands; $H_{e}=$ Nei's (1973) gene diversity or expected heterozygosity; Hpop = Shannon's information index (LEWONTIN, 1972) or observed heterozygosity. 
Table 4. - Matrix based on Nei's (1973) pairwise genetic distances between Cupressus gigantea populations obtained using ISSR (above diagonal) and RAPD (below diagonal) marker data.

\begin{tabular}{cccccc}
\hline Population & G1 & G2 & G3 & G4 & G5 \\
\hline G1 & $* * *$ & 0.3761 & 0.3853 & 0.4700 & 0.4276 \\
G2 & 0.3135 & $* * *$ & 0.2045 & 0.6480 & 0.5704 \\
G3 & 0.3197 & 0.1850 & $* * *$ & 0.5178 & 0.5038 \\
G4 & 0.3750 & 0.4769 & 0.4042 & $* * *$ & 0.6423 \\
G5 & 0.3479 & 0.4347 & 0.3958 & 0.4739 & $* * *$ \\
\hline
\end{tabular}

Table 5. - Analysis of Molecular Variance (AMOVA) for Cupressus gigantea populations using RAPD and ISSR markers.

\begin{tabular}{lcccccc}
\hline Source of variation & d.f & SSD & MSD & VC $^{\text {a }}$ & TV $(\%)^{\text {b }}$ & $P-$ value $^{\text {c }}$ \\
\hline RAPD & & & & & & \\
Among populations & 4 & 346.5260 & 86.631 & 4.967 & 49.73 & $<0.0010$ \\
Among individuals & 81 & 406.6601 & 5.020 & 5.020 & 50.27 & \\
ISSR & & & & & & \\
Among populations & 4 & 385.1335 & 96.283 & 5.337 & 38.34 & $<0.0010$ \\
Among individuals & 81 & 695.4130 & 8.585 & 8.585 & 61.66 & \\
\hline
\end{tabular}

a) Variance components; b) Percentage of total variance; ${ }^{\text {c) }} \mathrm{P}$ - value = probabilities calculated from 1000 random permutations of individuals across the populations.

average of 0.19 at the population level (Hpop) and 0.28 at the species level $(H s p)$. Genetic distances of paired populations calculated from ISSR and RAPD markers are shown in Table 4. All estimated genetic parameters were higher for ISSR markers than for RAPDs (Tables 2,3 and 4).

\section{Genetic partitioning among populations}

Both RAPD and ISSR markers revealed similar, high levels of genetic differentiation among populations. The coefficients of overall genetic differentiation between populations (Gst; estimated by the partitioning of the total gene diversity) were calculated as $40.2 \%$ and $36.3 \%$ for RAPD and ISSR markers, respectively. AMOVA analyses (Table 5) also suggested that there were significant $(\mathrm{P}<0.001)$ genetic differences $\left(\Phi_{\mathrm{ST}}\right)$ among the five populations; $49.7 \%$ (RAPDs) and $38.3 \%$ (ISSRs) of which was attributable to among-population variation and the rest to differences within populations (Table 5). The UPGMA dendrograms, based on the genetic distances between populations for ISSR and RAPD markers, are shown in Figure 2. For RAPDs, there are two distinct groups, Populations G2 and G3; and Populations G1, G4 and G5. In contrast, there is less of distinct grouping with the ISSR data. However, other than the two distinct groupings, the results are similar since in the ISSR data, populations G5, G4, G1 seem to be distinctly from one another and G2 and G3 are closely related.

\section{Discussion}

\section{Genetic partitioning within and among populations}

The genetic variation of $C$. gigantea $(45.4 \%$ and $69.2 \%$ of the total amplified bands were polymorphic for RAPD and ISSR markers, respectively) was similar to, or lower than, that reported for other conifers (JIMÉNEZ et al., 2003; WANG et al., 2004; AllnutT et al., 2003; CotTRELL et al., 2005; Petit et al., 2005; ZhANG et al., 2005). To our surprise, AMOVA indicated that $49.7 \%$ and $38.3 \%$ of the total variation recorded for RAPD and ISSR markers, respectively, was partitioned among populations and was consistent with Nei's genetic diversity analyses $\left(G_{\mathrm{ST}}=0.41, \mathrm{RAPD}\right.$ and $G_{\mathrm{ST}}=0.36$, ISSR $)$. These esti-
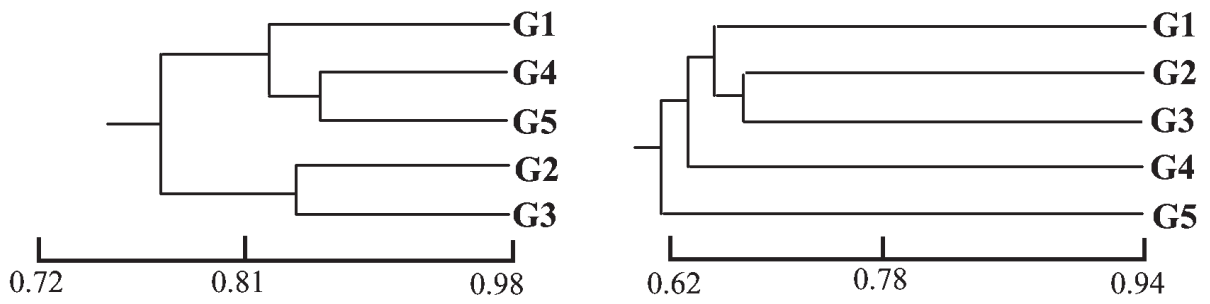

Figure 2. - UPGMA dendrogram (all individuals in one population form a single cluster) illustrating the genetic relationships between all populations of Cupressus gigantea calculated from the RAPD (left) and ISSR marker data (right). 
mates of differentiation among populations are much higher than corresponding coefficients reported for other conifer species of the same family based on estimates using RAPD or ISSR markers, e.g. Pilgerodendron uviferum $\left(\Phi_{\mathrm{ST}}=0.186\right.$, RAPD; AlLNUTT et al., 2003), Araucaria araucana (Molina) K. Koch. $\left(\Phi_{\mathrm{ST}}=0.128\right.$, RAPD, BEKESSY et al., 2002), Fitzroya cupressoides (Molina) I.M. Johnston $\left(\Phi_{\mathrm{ST}}=0.144\right.$, RAPD, ALLNUTT et al., 1999), Podocarpus salignus D. Don. $\left(\Phi_{\mathrm{ST}}=0.07\right.$, RAPD, ALLNUTT et al., 1999), and Calocedrus macrolepis $\left(\Phi_{\mathrm{ST}}=0.04\right.$, ISSR; WANG et al., 2004). Most gymnosperm species have low genetic differentiation among populations (similar to our results). HAMRICK and GODT (1989) reported a mean Gst value of 0.07 for 121 conifer species they examined, based on allozyme analyses. This tendency for gymnosperms to display low levels of population differentiation has been further confirmed by NYBOM and BARTISH (2000) based on a recent overview of RAPD analyses of plant species. Interspecific differences in the levels of among-population differentiation have been attributed to differences in breeding systems, lifehistory traits (NYBOM and BARTISH, 2000) and geographical distribution (LEE et al., 2002). However, compared with the above-listed conifer species from the same family, $C$. gigantea shows no distinct difference in its breeding system or life-history traits, except for a longer life cycle. In addition, all the investigated conifers mentioned above, including $C$. gigantea, are narrowly distributed with restricted ranges.

The climatic oscillations that occurred across the world during the Quaternary are considered to have strongly affected the distribution ranges of tree species (DumOLin-LapeÁ Gue et al., 1997; NEWTON et al., 1999; PETit et al., 2005). The population dynamics of various species may have been affected in two alternating ways by glaciation: shrinkage during glaciation, followed by expansion from refugia during postglacial recolonization, and survival of a few populations in situ (NEWTON et al., 1999). If all extant populations originated from a single refugium, it seems likely that there would be little among-population differentiation (NEWTON et al., 1999). This might account for the low levels of amongpopulation genetic differentiation reported for most species in the Cupressaceae (JIMÉNEZ et al., 2003; WANG et al., 2004; AllnUtT et al., 2003; CotTRELl et al., 2005; ZHANG et al., 2005). However, if the species survived in multiple refugia survived during glacial stages, the isolated populations probably experienced strong bottlenecks and severe genetic drift, resulting in elevated levels of genetic differentiation among populations (HewitT, 1996, 2000). Under this second scenario, C. gigantea may have survived in situ during the Quaternary due to its long life span. Subsequently, repeated reduction and expansion of the surviving populations during the climatic oscillations may have resulted in the high among-population differentiation detected in our study and resulted in further reductions in the total genetic diversity across all populations.

\section{Conservation and management}

Thorough understanding of the extent and patterns of genetic diversity in C. gigantea in the QTP is essential for its conservation and exploitation. It is important to understand where efforts should be focused to effectively manage and conserve populations of this species. Although a local natural protection area has been established for this species, it only includes the Linzhi population, which is the largest relic population (FU et al., 1999). The four populations we sampled outside the national protected area were genetically distinct from each other (Figure 2). According to the RAPD dendrogram, two distinct groups were recovered. The major population separation is due to longitudinal differences of populations (G4-G5 vs G1-G2-G3) and that there is an altitudinal separation between G1 vs G2-G3. Although the results based on the ISSR data failed to recover such two groups, populations G5, G4 and G1 seem to be distinct and G2 and G3 are closely related. The genetic relationships identified for the two markers were overall similar, and the minor difference detected between them probably reflected the difference in the sampled loci and the different evolutionary processes affecting the genomic regions amplified by the different markers. These results suggested that at least four conservation units comprising populations G1, G4, G5, G2 or G3 should be considered. The high differentiation and the inferred limited gene flow among populations also suggest that as many populations as possible should be used in artificial recruitment and re-planting programs in their original habitats. Therefore, additional populations should be used in conservation efforts if the full range of genetic variation within the species is to be maintained. In addition, losses of genetic diversity may reduce the viability and subsequent regeneration potential of this species (FRANKHAM et al., 2002). Efforts to understand the reduction in $C$. gigantea populations need to be coupled with research on the species' reproductive and demographic processes, especially with respect to the effects of different management strategies on the viability of its populations.

\section{Comparison of RAPD and ISSR data}

When the levels of variation detected using the RAPD and ISSR markers were compared, the ISSR primers were found to generate more polymorphic bands than the RAPD markers (Table 3). This trend has been repeatedly found in other herb species (e.g. QIAN et al., 2001). Microsatellites (ISSRs) are short tandem repeating DNA sequences whose repeat lengths are only a few base pairs long. These sequences are abundant and widely dispersed throughout the genomes of eukaryotic organisms and the high level of microsatellite polymorphism is due to DNA slippage, accounting for the difference between the ISSR and RAPD markers (WEBER and MAY, 1989). In addition, a distinct difference was detected in the average genetic distance between populations using the different markers. The inconsistencies between RAPD and ISSR patterns may be a result of the different evolutionary processes and selective forces acting on the genomic regions amplified by the two markers (QIAN et al., 2001). However, the total genetic diversity at the species level, and levels of population differentiation found using RAPD markers were similar to those identified using the ISSR markers, although the absolute values differed. The differences we detected 
between ISSR and RAPD markers are consistent with those found in studies of other species (NyBOM, 2004). In terms of amplification reproducibility, ISSR markers are more reliable than RAPDs. RAPDs are highly sensitive to PCR reaction conditions (FRITSCH and RIESEBERG, 1996) and a standard procedure must be established and conducted with caution to obtain good quality, reproducible bands. Less caution is required for ISSR markers, which are robust and less sensitive to PCR reaction conditions. The advantages of ISSRs, compared with RAPD markers, coupled with the higher levels of polymorphism they detect, lead us to conclude that ISSRs are superior markers for tree population genetics research.

\section{Acknowledgments}

Support for this research was provided by the National Natural Science Foundation of China (Grant number: 30430560), FANEDD (Grant number: 200327) and the special fund for outstanding $\mathrm{PhD}$ dissertations from the Chinese Academy of Sciences.

\section{References}

Allnutt, T. R., A. C. Newton, A. Lara, A. Premoli, J. J. Armesto, R. Vergara and M. Gardner (1999): Genetic variation in Fitzroya cupressoides (alerce), a threatened South American conifer. Molecular Ecology 8: 975-987.

Allnutt, T. R., A. C. Newton, A. Premoli and A. Lara (2003): Genetic variation in the threatened South American conifer Pilgerodendron uviferum (Cupressaceae), detected using RAPD markers. Biological Conservation 114: 245-253.

Bekessy, S. A., T. R. Allnutt, A. C. Premoli, A. Lara, R. A. Ennos, M. A. Burgman, M. Cortes and A. C. Newton (2002): Genetic variation in the Monkey Puzzle tree (Araucaria araucana (Molina) K. Koch), detected using RAPD. Heredity 88: 243-249.

Cottrell, J. E., V. KrystufeK, H. E. Tabbener, A. D. Milner, T. Connolly, L. Sing, S. Fluck, K. Burg, F. Lefevre and P. ACHARD (2005): Postglacial migration of Populus nigra L.: lessons learnt from chloroplast DNA. Forest Ecology and Management 206: 71-90.

Doyle, J. J. and J. L. DoYLE (1987): A rapid DNA isolation procedure for small quantities of fresh leaf material. Phytochemistry Bulletin 19: 11-15.

Dumolin-Lapeá Gue, S., B. Demesure, S. Fineschi, V. Le Corre and R. J. Petit (1997): Phylogeographic structure of white oaks throughout the European continent. Genetics 146: 1475-1487.

Excoffier, L., P. E. Smouse and J. M. QuatTro (1992): Analysis of molecular variance inferred from metric distances among DNA haplotypes: application to human mitochondrial DNA restriction data. Genetics 131: 479-91.

Frankham, R., J. D. Ballou and D. A. Briscoe (2002): Introduction to Conservation Genetics. Cambridge University Press, Cambridge, UK.

Fritsch, P. and L. H. RIESEBERG (1996): The use of Random Amplified Polymorphic DNA (RAPD) in conservation genetics, pp. 54-73. In: Molecular Genetic Approaches in Conservation, edited by T. B. SмITH, R. K. WAYNE, Oxford University Press, New York.

FU, L. G. (1995): China Plant Red Data Book. Science Press, Beijing.
FU, L. G., Y. F. YU and A. FARJON (1999): Cupressaceae, 4, pp. 62-65. In: Flora of China, edited by P. H. RAVEN, C. Y. Wu, Science Press, Beijing, and Missouri Botanical Garden Press, St. Louis.

Gillies, A. C. M., J. P. Cornelius, A. C. Newton, C. Navarro, M. Hernández and J. Wilson (1997): Genetic variation in Costa Rican populations of the tropical timber species Cedrela odorata L. assessed using RAPDs. Molecular Ecology 6: 1133-1145.

Gillies, A. C. M., C. Navarro, A. J. Lowe, A. C. Newton, M. Hernández, J. Wilson and J. P. Cornelius (1999): Genetic diversity in Mesoamerican populations of mahogany (Swietenia macrophylla), assessed using RAPDs. Heredity 83: 722-732.

HAMRICK, J. L. and M. J. W. GoDT (1989): Allozyme diversity in plant species, pp. 43-63 In: Plant Population Genetics, Breeding and Genetic Resources, edited by A. H. D. Brown, M. T. ClegG, A. L. Kahler, B. S. Weir, Sinauer, Sunderland, MA.

HAMrick, J. L., M. J. W. GodT and S. L. Sherman-Broyles (1992): Factors influencing levels of genetic diversity in woody plant species. New Forest 6: 95-124.

HEDRICK, P. W. (2004): Recent developments in conservation genetics. Forest Ecology and Management 197: 3-19.

HewitT, G. M. (1996): Some genetic consequences of ice ages, and their role in divergence and speciation. Biological Journal of the Linnean Society 58: 247-276.

HewitT, G. M. (2000): The genetic legacy of the Quaternary ice ages. Nature 405: 907-913.

HuH, M. K. and H. W. HuH (2000): Genetic diversity and population structure of Juniperus rigida (Cupressaceae) and Juniperus coreana. Evolutionary Ecology 14: 87-98.

Jiménez, J. F., O. WeRner, P. SÁnchez-Gómez, S. FERnÁNDEZ and J. GUERRA (2003): Genetic variations and migration pathway of Juniperus thurifera L. (Cupressaceae) in the western Mediterranean region. Israel Journal of Plant Sciences 51: 11-22.

Kremer, A. and M. P. Reviron (2004): Dynamics and conservation of genetic diversity in forest ecosystems. Forest Ecology and Management 197: 1-2.

LEDIG, F. T. (1987): Genetic structure and the conservation of California's endemic and near-endemic conifers, pp. 587-594. In: Conservation and Management of Rare and Endangered Plants edited by T. S. ELLIS, California Native Plant Society, Sacramento, USA.

LEE, S. W., F. T. LEDIG and D. R. JoHnson (2002): Genetic variation at allozyme and RAPD markers in Pinus longaeva (Pinaceae) of the white mountains. California. American Journal of Botany 89: 566-577.

MilleR, M. P. (1998): AMOVA-PREP 1.01: A program for the preparation of AMOVA input files from dominantmarkers raw data. Computer software distributed by author.

Myers, N., R. A. Mittermeier, C. G. MittermeieR, G. A. B. DA FonsecA and J. Kent (2000): Biodiversity hotspots for conservation priorities. Nature 403: 853-858.

NAEP (National Administration of Environmental Protection), IBCAS (Institute of Botany, Chinese Academy of Sciences), 1987. The List of Rare and Endangered Plants Protected in China, Science Press, Beijing.

NEI, M. (1973): Analysis of gene diversity in subdivided populations. Proceedings of the National Academic Sciences USA 70: 3321-3323. 
Newton, A. C., T. Allnutt, A. C. M. Gillies, A. Lowe and R. A. EnNos (1999): Molecular phylogeography, intraspecific variation and the conservation of tree species. Trends Ecology and Evolution 14: 140-145.

NyBom, H. and I. BARTISH (2000): Effects of life history traits and sampling strategies on genetic diversity estimates obtained with RAPD markers in plants. Perspectives in Plant Ecology, Evolution and Systematics 3: 93-114.

Nyвом, H. (2004): Comparison of different nuclear DNA markers for estimating intraspecific genetic diversity in plants. Molecular Ecology 13: 1143-1155.

Petit, R. J., R. BialozyT, P. Garnier-GÉréand and A. HAMPE (2004): Ecology and genetics of tree invasions: from recent introductions to Quaternary migrations. Forest Ecology and Management 197: 117-137.

Petit, R. J., J. Duminil, S. Fineschi, A. Hampe, D. SAlvin and G. G. VendRAmin (2005): Comparative organization of chloroplast, mitochondrial and nuclear diversity in plant populations. Molecular Ecology 14: 689-701.

QIAN, W., S. GE and D. Y. HoNG (2001): Genetic variation within and among populations of a wild rice Oryza granulata from China detected by RAPD and ISSR markers. Theoretical and Applied Genetics 102: 440-449.

RADDI, S. and S. SUEMER (1999): Genetic diversity in natural Cupressus sempervirens L. populations in Turkey. Biochemical Systematics and Ecology 27: 799-814.

REED, D. H. (2003): Correlation between fitness and genetic diversity. Conservation Biology 17: 230-237.
RoHLF, F. J. (1998): NTSYS-pc 2. Numerical Taxonomy and Multivariate Analysis System. Exeter Software, New York.

Wang, D. L., Z. C. Li, G. HaO, T. Y. Chiang and X. J. GE (2004): Genetic diversity of Calocedrus macrolepis (Cupressaceae) in southwestern China. Biochemical Systematics and Ecology 32: 797-807.

WANG, X. R. and A. E. SzMIDT (2001): Molecular markers in population genetics of forest trees. Scandinavian Journal of Forest Research 16: 199-220.

WEBER, J. L. and P. E. MAY (1989): Abundant class of human DNA polymorphism which can be typed using the polymerase chain reaction. American Journal of Human Genetics 44: 388-396.

Wolfe, A. D., Q. Y. Xiang and S. R. Kephart (1998): Assessing hybridization in natural population of Penstemon (Scrophulariaceae) using hypervariable intersimple sequence repeat (ISSR) bands. Molecular Ecology 7: 1107-1125.

Yeh, F. C., R. YAng and T. Boyle (1999): POPGENE. Microsoft Windows-based freeware for population genetic analysis. Release 1.31. University of Alberta, Edmonton, Canada.

Zhang, Q., T. Y. ChiAng, G. Miehe, J. Q. LiU and R. Аввотт (2005): Phylogeography of the QinghaiTibetan Plateau endemic Juniperus przewalskii inferred from chloroplast sequence variation. Molecular Ecology 14: 3513-3524. 